Muhammad Rizky Wahyudi, Zikri Alhadi I Pendekatan dalam Mitigasi Bencana Tanah Longsor di Kenagarian Sungai Landia Kecamatan IV Koto Kabupaten Agam

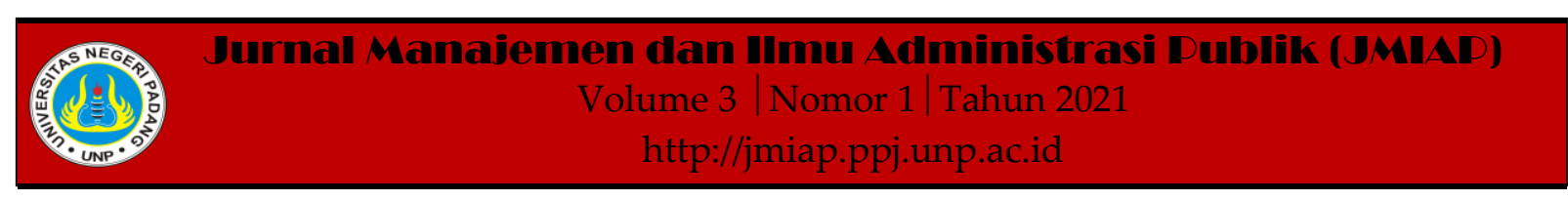

\title{
PENDEKATAN DALAM MITIGASI BENCANA TANAH LONGSOR DI KENAGARIAN SUNGAI LANDIA KECAMATAN IV KOTO KABUPATEN AGAM
}

\author{
Muhammad Rizky Wahyudi ${ }^{1(a)}$, Zikri Alhadi ${ }^{2(b)}$ \\ ${ }^{1}$ Jurusan Ilmu Administrasi Negara, Universitas Negeri Padang \\ ${ }^{2}$ Jurusan Ilmu Administrasi Negara, Universitas Negeri Padang \\ ${ }^{a)}$ wahyudirizky802@gamil.com, ${ }^{b)}$ the.zikrialhadi@gmail.com
}

\begin{abstract}
This study aims to determine the approach to landslide disaster mitigation in Kenagarian Sungai Landia, IV Koto Subdistrict, which is carried out by the Agam District Disaster Management Agency and also by the Sungai Landia village government. This research method is a qualitative method with descriptive type. The research location is in the office of the Regional Disaster Management Agency of Agam Regency and the office of the Wali Nagari Sungai Landia. Data collection using caca interviews, observation, and study documentation. The research informants were several heads of fields, section heads in the Regional Disaster Management Agency of Agam Regency, Wali Nagari Sungai Landia and several staff, several high-ranking officials of the Landia River Kenagarian and the Kenagarian Sungai Landia community. The results showed that mitigation measures had been taken, but the mitigation measures had not been maximally implemented by the Agam District BPBD and the Sungai Landia village government.

Keywords : Mitigation, Disasters, landslide, Kenagarian Sungai Landia

Corresponding author. Email.wahyudirizky802@gamil.com

How to cite this article. Wahyudi, M. Rizky \& Alhadi, Z. (2021). Pendekatan dalam Mitigasi Bencana Tanah Longsor di Kenagarian Sungai Landia Kecamatan IV Koto Kabupaten Agam. Jurnal Manajemen dan Ilmu Administrasi Publik (JMIAP) Jurusan Ilmu Administrasi Negara Fakultas Ilmu Sosial Universitas Negeri Padang, Volume 3 (1), Hal. 47-55.

http://jmiap.ppj.unp.ac.id

Copyright $@ 2021$. Published by Labor Jurusan Ilmu Administrasi Negara FIS UNP, Padang
\end{abstract}




\section{PENDAHULUAN}

Sesuai dengan Undang-Undang Nomor 24 Tahun 2007, bencana bisa diartikan sebagai suatu kejadian atau deretan kejadian yang dapat menyebabkan ancaman serta merusak kehidupan serta juga mata pecarian masyarakat yang disebabkan, oleh berbagai faktor seperti faktor alam atau faktor non alam dan juga disebabkan oleh faktor manusia sehingga bisa saja membuat terjadinya korban jiwa manusia, rusaknya lingkungan, kerugian harta benda dan imbasnya terhadap psikologis.

Menurut Asian Disaster Reduction Center (2003) yang dikutip Wijayanto (2012), Bencana yaitu suatu guncangan serius yang terjadi dan dirasakan oleh masyarakat yang bisa saja mengakibatkan kehilangan secara keseluruhan dapat dirasakan baik oleh masyarakat, berbagai bentuk bangunan dan lingkungan (alam) dimana akibat yang didapatkan dari bencana ini melamapaui dari kapabilitas manusia itu sendiri.

Selanjutnya Carter dalam Muis (2018) juga menjelaskan bencana sebagai bentuk dari kejadian, alam atau buatan manusia, timbul secara mendadak atau progresive, yang membuat suatu imbas yang dahsyat (hebat) dan bisa membuat masyarakat yang terimbas atau terpengaruh harus mmelakukan respon dengan perbuatanperbuatan yang luar biasa juga.

Menurut Parker (1992) dalam Wijayanto (2012), bencana yaitu suatu bentuk dari kejadian yang diluar akal terjadi dikarenakan oleh alam serta ulah manusia, dan bisa juga terjadi akibat yang disebabkan dari kegagalan perkembangan teknologi yang mengakibatkan terjadinya respon dari masyarakat, kelompok, individu maupun lingkungan guna memberikan antusiasme yang bersifat secara menyeluruh. Menurut UndangUndang Nomor 24 Tahun 2007 Pasal 1 ayat (2), (3) dan (4) tentang penanggulangan bencana, bencana dikelompokkan kedalam tiga (3) bentuk, yaitu : a. Bencana alam yaitu bencana yang disebabkan oleh berbagai kejadian atau deretan kejadian yang diakibatkan oleh alam itu sendiri seperti tsunami, gempa bumi, najir, dan tanah longosr.

b. Bencana yang tidak terjadi akibat alam merupakan bencana yang ditimbulkan oleh berbagai kejadian atau deretan kejadian non alam antara lain berupa gagal dalam hal teknologi, tidak berhasilnya modernisasi, wabah penyakit atau pandemi dan epidemi.

c. Bencana sosial merupakan suatu bencana yang ditimbulkan atas berbagai kejadian atau serangkaian kejadian yang terjadi akibat dari masyarakat setempat kejadian seperti masalah sosial masyarakat serta kelompok atau komunitas dan juga teror.

Dalam pernyataan diatas terdapat suatu makna, yaitu semua warga negara harus bisa mendapatkan perlindungan hak - hak dasar, dan juga berbagai bentuk perlindungan untuk terhindar dari rasa takut, ancaman, resiko dampak bencana. Sadar akan situasi tersebut bahwa pemerintah telah melakukan pembentukan lembaga khusus yaitu Badan Nasional Penanggulangan Bencana (BNPB) selaku kaki tangan pemerintah guna untuk menanggulangi bencana, BNPB dibentuk berlandaskan pada Peraturan Presiden Nomor 8 tahun 2008.

Suatu kewajiban bagi setiap pemerintah untuk memberikan suatu bentuk perlindungan terhadap penanggulangan bencana yang termaktub pada suatu lingkup manajeman bencana yang efektif dan efisien, terkhusus dalam hal penanggulangan becana longsor. Penanggulangan bencana tanah longsor tidak akan bisa dilaksanakan secara satu pihak saja yaitu oleh pemerintah, akan tetapi seluruh pihak yang terdampak juga harus ikut serta dengan aktif pada saat penaggulangan benacan alam.

Tanah longsor yaitu suatu bentuk dari pindahnya material pembentuk lereng berupa bebatuan, bahan rombakan, tanah 
atau material laporan bergerak ke bawah atau keluar dari lereng. Secara geolologis tanah longsor adalah salah satu bentuk kejadian dari geologi yang mengakibatkan pergerakan tanah seperti jatuhnya bebatuan atau gumpalan besar dari tanah (Nandi, 2007:6).

Tanah longsor atau yang biasa diketahui terjadinya gerakan atau hentakan massa tanah yaitu merupakan sebuah bentuk dari kerusakan alam yang sudah menimbulkan berbagai resiko dan dampak baik pada dampak sosial dan dampak ekonomi untuk masyarakat yang terkena dari kerusakan alam tersebut, seperti; hancurnya prasarana dan sarana serta korban jiwa yang disebabkan oleh tanah longsor bisa dikatakan banyak. Oleh sebab itu, sangat diperlukan sebuah langkah mitigasi bencana agar dampak yang disebabkan oleh tanah longsor bisa berkurang. Pendapat yang dinyatakan oleh Karnawati (2005), ketika telah terjadi gerakan massa tanah disebabkan karena terganggunya keseimbangan pada objek tanah atau pertolongan pada batuan pembentukkan lereng, jadi berat tanah atau batuan penyusun lereng ataupun campuran dari keduanya mengalami gerakan menuruni lereng.

Bencana alam tanah longsor bisa saja terjadi karena bentuk dari pada pemakaian berbagai lahan yang tidak berdasarkan dengan aturan kelestarian lingkungan, misalnya seperti peruasakan dan penebangan hutan yang nanti akan menyebabkan penyusupan air hujan yang tinggi berjalan dengan lancar. Hujan lebat ketika terjadi pada awal musim bisa menyebabkan suatu kerusakan alam seperti terjadinya; longsor. Sebab terjadinya longsor dapat dikejar karena terjadi adanya hujan yang sangat deras dan lebat yang timbul secara tiba-tiba, yang mana nantinya mengakibatkan tanah tidak akan mampu menahan genangan curah hujan dan tergelincir ke bawah (Anwar, 2012).

Mitigasi bencana merupakan suatu cara untuk menurunkan resiko bencana yang terjadi sehingga akibat yang terjadi dari sebuah bencana tersebut. tindakan dari sebuah mitigasi bisa berupa teknik - teknik rekayasa dan konstruksi yang cepat akan sebuah risiko bahaya beserta peraturan tentang lingkungan yang lebih baik dan membuat masyarakat sadar akan bahaya tersebut. Dari batasan ini bisa dikatakan bahwa mitigasi bersifat mencegah agar bencana tidak terjadi. Upaya dan pendekatan dalam mitigasi bencana adalah sebagai berikut (Ramli, 2010: 32):

\section{Pendekatan Teknis}

Pada pendekatan teknis ini mitigasi bencana yang dilakukan guna untuk memperkecil dampak dari bencana tersebut, seperti:

a) Merancang dan memdesain sebuah bangunan yang kuat agar tahan dari gempa bumi.

b) Menentukan bahan-bahan material yang tahan dari kejadian bencana.

c) Menyiapkan bagan teknis keamanan.

2. Pendekatan Manusia

Pendekatan ini bertujuan untuk membangun persepsi masyarakat agar paham mengenai bahaya dari bencana alam. Dari hal ini masyarakat harus mampu memperbaiki dan menyesuaikan diri dengan lingkungan dan semua gelajagejala dari potensi bencana alam yang ada.

3. Pendekatan Administrasi

Dalam hal ini pendekatan administrasi ialah melakukan manajemen dari akibat bencana yang akan ditimbulkan tersebut, seperti;

a) Pembentukan dari tata ruang dan lahan yang harus diperhitungkan segi resikan dan bencananya.

b) Sistem pembuatan dan pembentukan izin dengan nantinya bisa memasukkan aspek analisa risiko bencana.

\section{Pendekatan Kultural}

Pada pendekatan ini, pencegahan bencana alam diterapkan dengan konsep kearifan lokal yang telah membudaya sejak dulu. Bentuk dari pengendalian ini bisa disesuaikan melalui budaya yang ada di 
daerah tersebut serta tradisi yang berada serta berkembang di tengah - tengah masyarakat.

Kecamatan IV koto yaitu salah satu dari kecamatan yang berada di Kabupaten Agam, Provinsi Sumatera Barat, Kecamatan ini terletak dikaki Gunung Singgalang dan merupakan salah satu dari beberapa kecamatan di Kabupaten Agam yang memiliki resiko rawan longsor karena memiliki bentuk wilayah yang didominasi oleh lereng-lereng bukit yang curam serta juga memiliki curah hujan yang tinggi.

Selanjutnya data Kementrian Energi dan Sumber Daya Mineral Badan Geologi (2017), Kecamatan IV Koto memiliki potensi gerakan tanah dari menengah hingga tinggi. Pada daerah yang memiliki potensi menengah untuk terjadi gerakan tanah, pada daerah ini dapat terjadi gerakan tanah jika curah hujan diatas rata-rata atau hujan lebat, terutama pada daerah yang berbekatan langsung dengan lembah sungai, gawir, tebing jalan atau jika lereng mengalami kerusakan. Sementara pada daerah yang memiliki potensi tinggi untuk terjadi gerakan tanah pada zona ini dapat terjadi gerakan tanah jika curah hujan diatas rata - rata, sementara itu gerakan tanah yang lama juga bisa aktif kembali lagi dan juga nantinya bisa menimbulkan longsor.

Setiap tahunnya pasti terjadi longsor, karena hujan yang berkepanjangan setiap akhir tahun. Itu artinya perlu penanganan yang sangat cepat dan juga pencegahan yang harus dilaksanakan oleh pemerintah supaya tidak terjadinya kejadian yang tidak diinginkan.

Melihat banyaknya kerugian setiap tahunnya yang dihadapi oleh masyarakat maka penanganan masalah tanah longsor harus ditangani dengan serius oleh pemerintah khususnya. Maka bentuk dari penanggulangan bencana di daerah harus dilaksanakan harus berdasarkan dengan adanya kebijakan daerah setempat yang nantinya bertujuan untuk menanggulangi bencana berdasarkan dengan peraturan yang ada. Bentuk dari rencana yang ditetapkan daerah dalam menanggulangi bencana harus dilihat juga berdasarkan dengan kondisi daerah. Operasi penanggulangan bencana secara nasional harus dipastikan berlangsung sacara efektif, efisien dan berkelanjutan.

Berdasarkan peristiwa bencana tanah longsor yang melanda daerah Keamatan IV Koto khususnya Kenagarian Sungai Landia tiap tahunnya dan menimbulkan dampak luas baik secara moril maupun materi serta belum maksimalnya penanganan dari pihak yang bertanggung jawab/terkait. Berdasarkan hal tersebut terdapat beberapa permasalahan maka penulis mengidentifikasi beberapa masalah; hujan lebat yang terjadi setiap tahunnya mengakibatkan terjadinya bencana tanah longsor di kenagarian Sungai Landia, tanah longsor yang terjadi di kanagarian Sungai Landia mengakibatkan lalu lintas menjadi terhambat, penanganan atau mitigasi bencana tanah longsor yang belum maksimal dilaksanakan oleh pemerintah, pemerintah baru bergerak setelah terjadinya bencana dan tidak ada upaya pencegahan yang dilakukan pemerintah.

Berdasarkan permasalahan yang penulis paparkan maka rumusan masalah pada penelitian ini ialah; bagaimana pendekatan mitigasi bencana tanah longsor di Kenagarian Sungai Landia kecamatan IV Koto.

\section{TINJAUAN PUSTAKA \\ Konsep Bencana}

Sesuai dengan Undang-Undang Nomor 24 Tahun 2007, bencana bisa diartikan sebagai salah satu kejadian atau deretan kejadian yang dapat mengancam dan mengganggu kehidupan serta juga mata pecarian masyarakat yang ditimbulkan oleh berbagai faktor seperti faktor alam atau faktor non alam dan juga disebabkan oleh faktor manusia sehingga menyebabkan adanya korban jiwa manusia, rusaknya lingkungan, kerugian harta benda dan imbasnya terhadap psikologis masyarakat. 
Muhammad Rizky Wahyudi, Zikri Alhadi I Pendekatan dalam Mitigasi Bencana Tanah Longsor di Kenagarian Sungai Landia Kecamatan IV Koto Kabupaten Agam

Arie Priambodo (2010: 22) mendefinisikan Bencana sebagai suatu bentuk dari kejadian yang ditimbulkan oleh alam, ulah manusia, dan juga kombinasi antar keduanya yang terjadi secara tiba-tiba sehingga menyebabkan terjadinya akibat negatif yang dahsyat bagi kelangsungan hidup masyarakat setempat. Pada peristiwa tersebut, unsur yang terkait langsung atau terpengaruh harus merespons dengan melakukan perbuatan yang bisa dibilang luar biasa untuk menyesuaikan sekaligus memperbaiki semua keadaan seperti semula dan menjadi lebih baik.

\section{Tanah Longsor}

Tanah longsor bisa dikakatan sebagai suatu bentuk dari proses geologi yang juga biasa dikatakan dengan pergeseran unsur dari tanah yang bisa diartikan sebagai gerakan berat tanah, yaitu bentuk pergeseran berat batuan dan tanah mulai dari tempat yang tinggi hingga ke tempat yang lebih rendah akibat dari gaya gravitasi. Sesudah batuan lepuk, gaya gravitasi ini menyebakan timbulnya ketertarikan bahan hasil pelepukan ke tempat yang lebih rendah. Dilihat dari akibat yang ditirnbulkan pada saat timbulnya bencana tanah longsor, bahwa pengenalan dari tempat insiden tanah longsor penting untuk dilakukan supaya bisa untuk mengetahui pemicu utama longsor dan ciri-ciri dari setiap kejadian longsor sehingga dapat menjadi petunjuk dalam mitigasi bencana longsor selanjutnya. Pengenalan dari daerah kejadian longsor juga perlu agar bisa mengetahui hubungan antara lokasi kejadian longsor dengan faktor penyebaran batuan dan tata gunalahan di daerah terjadinya longsor, sehingga bisa diketahui tata gunalahan yang sesuai dengan ciri-ciri lahan dan geologinya.

\section{Konsep Manajemen Bencana}

Shaluf dalam Kusumasari (2010:19) menyebutkan manajemen bencana yaitu sebagai suatu istilah kolektif yang mencakup semua bentuk dari perencanaan untuk merespons bencana, termasuk aktivitas yang terjadi sebelum bencana dan setelah terjadinya bencana yang bisa jadi juga melihat kepada konsep manajemen resiko dan konsekuensi bencana.

Kegiatan manajemen bencana bisa pecah menjadi 3 kegiatan utama, yaitu:

a) Kegiatan pra bencana yang termasuk didalamnya adalah kegiatan pencegahan, mitigasi, kesiapsiagaan, serta peringatan dini bencana. Kegaiatan pada saat pra bencana ini adalah dengan melakukan persiapan persiapan seperti contohnya menyiapkan kegiatan seperti pelatihan kepada masyarakat, pembuatan tempat evakuasi bagi masyarakat jika terjadi bencana dan kegiatan - kegaiatan yang nantinya dibutuhkan jika benacana terjadi.. Pemerintahan bersama dengan masyarakat maupun swasta sangat sedikit yang mernikirkan tentang langkah-langkah atau kegiatan-kegiatan apa yang perlu dilakukan di dalam menghadapi bencana atau bagaimana memperkecil dampak bencana.

b) Kegiatan bencana, maksudnya kegiatan ini dilaksanakan pada waktu bencana alam terjadi, dengan mempersiapkan segala sesuatu seperti search and rescue (SAR)myang nantinya tim SAR ini lah yang bergerak pada saat bencana terjadi di suatu tempat. Tim SAR ini bertugas untuk meringankan penderitaan sementara yang dilakukan pada saat bencana alam terjad serta bantuan darurat dan pengungsian. Kegiatan pada saat bencana juga berupa pembuatan tempat evakuasi dan juga pengungsian terhadap korban bencana dengan tujuan untuk mengurangi dampak terhadap koran bencana lama tersebut. Pada saat bencana itu berlangsung, biasanya ada banyak sekali pihak-pihak yang ikut dalam memberikan bantuan, baik bantuan tanaga, moril maupun dalam bentuk logistik untuk para korban bencana. 
c) Kegiatan pasca bencana, kegiatan ini mencakup pada saat bencana telah selesai, seperti kegiatan pembersihan tempat yang terdampak, rahbilitasi terhadap korban, dan juga reskonruksi bangunan. Kegiatan ini sangat diperlukan untuk memulihkan kembali trauma - trauma korban yang terdampak, dan juga pemulihan pemulihan tempat yang hancur akibat terkena bencana seperti memperbaiki gedung - gedung yang hancur, urmahrumah masyarakat dan juga jalan yang sudah tidak bisa dilalui.

\section{Mitigasi Bencana}

Mitigasi bencana yaitu suatu bentuk dari tuntutan daerah kota/kabupaten yang mempunyai bentuk dari kerawanan bencananya yang rendah hingga bentuk dari kerawanannya yang sangat amat tinggi. Konsep dari mitigasi bencana yaitu sebagai salah satu bentuk tahap awal dalam manajemen bencana yang memiliki keterikatan yang sama dengan proses kebijakan publik dimana perlu menentukan posisi mitigasi bencana untuk dijadikan keputusan pada saat pelaksanaan kebijakan publik. Dengan mempertimbangkan berbagai bentuk dari bagian mitigasi bencana bisa dikatakan bahwa mitigasi bencana juga salah satu dari kegiatan kebijakan evaluatif yang menimbulkan adanya perumusan kembali dari suatu kebijakan tersebut (Faturahman, 2018 dalam Lugas Yan Prastowo dan Anik Setyo Wahyuningsih, 2020).

Mitigasi bencana merupakan suatu cara untuk menurunkan resiko bencana yang terjadi sehingga akibat yang terjadi dari sebuah bencana tersebut. tindakan dari sebuah mitigasi bisa berupa teknik - teknik rekayasa dan konstruksi yang cepat akan sebuah risiko bahaya beserta peraturan tentang lingkungan yang lebih baik dan membuat masyarakat sadar akan bahaya tersebut.

\section{METODE PENELITIAN}

Penelitian ini merupakan penelitian kualitatif dengan metode deskriptif. Informan yang ada pada penelitian ini ditentukan dengan menggunakan cara purpose sampling, untuk menentukan informan kunci dan informan selanjutnya ditentukan dengan teknik Snowball Sampling. Teknik pengumpulan data dengan cara observasi, wawancara dan studi dokumentasi. Untuk analisa data dpeneliti melakukan cara pengumpulan data, reduksi data, penyajian data, dan penarikan kesimpulan. Dalam menguji keabsahan data digunakan Triangulasi Sumber yang selanjutnya di analisis dengan teknik analisis data. Pengukuran terhadap pendekatan dalam Mitigasi Bencana Tanah Longsor di Kenagarian Sungai Landia Kecamatan IV Koto Kabupaten Agam peneliti menggunakan pendekatan mitigasi yang dikemukakan oleh Ramli (2010) yaitu Pendekatan Teknis dalam mitigasi, pendekatan manusia dalam mitigasi, pendekatan adminitrasi dalam mitigasi dan pendekatan kultural dalam mitigasi.

\section{HASIL DAN PEMBAHASAN Pendekatan Teknis}

Pemerintah kenagarian sungai landia sudah berupaya dengan melakukan pembuatan rancangan kokoh bencana dengan melakukan penanaman berbagai macam pohon yang juga bermanfaat bagi masyarakat kenagarian sungai landia dan juga dapat mengantisipasi bencana tanah longsor, tetapi masih belum efektif karena ada beberapa masyarakat yang melakukan penebangan liar. Namun, kalau dilihat bahwa penanaman pohon ini juga belum efektif karena lamanya pertumbuhan pohon tersebut yang bisa memakan waktu bertahun-tahun. Dan pada saat menunggu pohon tumbuh, penebangan liar juga semakin banyak, sehingga hutan atau lahan dinagari sungai landia semakin gundul dan menyebabkan bencana tanah longsor selalu terjadi. masyarakat setempat sudah mulai sadar akan bahaya yang dirimbulkan dari 
bencana tanah longsor ini, dan masyarakat setempat yang dibantu oleh pemerintah nagari juga berupaya agar tanah dikenagarian sungai landia kokoh akan bencana tanah longsor. BPBD Kabupaten Agam menyiapkan kelompok siaga bencana untuk penanganan awal dari bencana yang terjadi, karna belum tentu tim dari BPBD bergerak cepat, karena terkendala jarak yang cukup jauh terutama di kenagarian sungai landia, sehingga kelompok siaga bencana ini sangat dibutuhkan jika bencana alam terjadi ditempat-tempat yang jauh dari kantor BPBD sendiri, jadi KSB ini sangat berguna jika ada kejadian bencana yang terjadi jauh dari ibukota kabupaten atau kantor BPBD Agam, walaupun bencana terjadi secara tiba-tiba pada saat malam hari, KSB yang bertindak terlebih dahulu dalam hal penanggulangan bencana ini. Sehingga dapat disimpulkan bahwa dalam pendekatan teknis ini belum dilakukan secara maksimal.

\section{Pendekatan Manusia}

Masyarakat sudah mulai sadar akan bahayanya bencana tanah longsor ini, dan ketika hujan lebat datang pemerintah setempat dan juga masyarakat mulai waspada akan datangnya bencana tanah longsor ini serta menyiapkan diri mereka seandainya bahaya itu datang. Namun ada beberapa masyarakat yang tidak peduli dengan adanya bahaya tanah longsor ini, mereka melakukan penebangan secara liar yang nantinya akan mengakibatkan terjadinya bencana tanah longsor yang akan bertambah lagi setiap tahunnya. Pada pendekatan teknis dapat disimpulkan bahwa masyarakat secara sukarela membantu pemerintah dalam penanganan tanah longsor tersebut, serta masyarakat setempat juga mau meminta tambahan dana untuk perbaikan tempat yang terkena dampak dari bencana tanah longsor tersebut dengan melakukan penggalangan dana yang dilakukan dijalan tempat kejadian bencana tersebut berlangsung, yang mana sumber dari dana sumbangan tersebut berasal dari pengendara yang lewat ditempat kejadian tersebut. Namun perbaikan jalan bekas tanah longsor itu sendiri belum diperbaiki hingga saat ini, bisa disimpulkan bahwa penanganan saat terjadi bencana cukup cepat, namun pada saat pasca bencana penangannya sangat lambat.

\section{Pendekatan Administrasi}

Tata lahan dikenagarian sungai landia pada saat sekarang masih berpotensi terjadi bencana lagi, maka dari itu pemerintah setempat sudah berencana untuk meminta kepada pemerintah daerah untuk pembuatan pondasi tahan bencana tanah longsor. pemerintah setempat sudah berencana melakukan pelatihan bencana, namun pelatihan ini tertunda dikarenakan adanya pandemi covid-19, sehingga masyarakat setempat masih belum paaham terhadap apa yang mereka lakukan jika suatu saat beencana tanah longsor terjadi didaerah mereka. Namun pemerintah kenagarian sungai landia sudah berencana untuk melakukan pelatihan kebencanaan ini pada tahun 2021, jika wabah COVID19 ini berakhir, dan jika belum berakhir maka pelatihan ini akan tertunda lagi sampai wabah ini berhenti. pemerintah nagari sungai landia merancang peta rawan bencana yang mana berfungsi agar pemerintah dan masyarakat bisa waspada akan datangnya bencana tanah longsor tersebut, namun hingga saat ini peta topogrfi tersebut belum ada, sehingga masyarakat dan pemerintah hanya mengira-mengira tempat yang akan berpotensi terjadi bencana tanah longsor tersebut dan waspada jika terjadi hujan yang sangat lebat melanda kenagarian sungai landia.

\section{Pendekatan Kultural}

Masyarakat sungai landia melalui pengumuman dari petinggi - petinggi adat dan juga pemerintah akan menjauhi daerah atau tempat yang berpotensi terjadi bencana, dengan melihat tanda-tandanya yaitu seperti hujan yang sangat lebat serta 
air hujan yang jatuh kejalan sudah berubah warna menjadi warna tanah, jadi masyarakat Sungai Landia serta pemerintah sudah mewanti-wanti dari awal jika hujan lebat yang berpotensi bencana tanah longsor. pemangku adat disungai landia juga sudah berupaya dengan semaksimal mungkin agar semua masyarakat dapat terhindar dari bencana tanah longsor yang tidak tau kaan terjadinya, dan selalu berupaya semaksimal mungkin agar bencana ini tidak terjadi lagi, walaupun bencana tanah longsor di kenagarian Sungai Landia terjadi setiap tahunnya, dan pemerintah selalu berupaya semaksimal mungkin agar bencana berkurang bahkan bencana tanah longsor tidak terjadi lagi.

\section{PENUTUP}

Yang pertama yaitu pendekatan teknis dalam mitigasi bencana tanah longsor. berdasarkan temuan dilapangan, peneliti menemukan bahwa pemerintah nagari Sungai Landia sudah membuat rancangan kokoh bencana dengan melakukan penanaman pohon disekitar tempat rawan bencana tanah longsor, namun hal ini bisa dikatakan belum efektif sebab untuk menunggu tumbuhnya pohon-pohon tersebut bisa menghasilkan waktu yang lam, serta masih adanya beberapa masyarakat yang melakukan penebangan pohon secara liar yang membuat lahan rawan longsor semakin gundul. Dan dari BPBD Agam sendiri juga menyiapkan kelompok siaga bencana yang mana kelompok siaga bencana yang ditugaskan disetiap nagari yang ada di Kabupaten Agam, dan nantinya Kelompok siaga benacana ini lah yang akan bergerak cepat jika terjadi bencana di Kabupaten Agam.

Yang kedua yaitu melakukan pendekatan Manusia, dimana dalam pendekatan manusia ini bahwa masyarakat di kenagarian sungai landia sudah mulai sadar akan bahayanya bencana tanah longsor yang terjadi di Kenagarian Sungai Landia ini, jadi masyarakat setempat juga berinisiatif untuk melakukan gotong royong pembersihan tempat terjadinya bencana, dan juga masyarakat juga melakukan penanaman pohon yang sudah di siapkan oleh pemerintah kenagarian sungai landia.

Yang ketiga yaitu melalai pendekatan adminitrasi, pemerintah kenagarian sungai landia sudah melakukan permohonan agar pemerintah kabupaten untuk membuat pondasi serta selokan yang berbahan batu untuk tanah yang tidak bisa ditanami pohon agar menahan tanah tersebut agar tidak terjadi longsor, dan juga pemerintah akan melakukan pelatihan terhadap masyarakat agar mereka cepat dan tanggap jika terjadi bencana di daerah tersebut.

Yang keempat adalah pendekatan kultural, dimana di kenagarian sungai landia ini, masyarakat dan petinggi adat mempunyai tradisi jika bencana terjadi yaitu, melihat tanda-tandanya yaitu seperti hujan yang sangat lebat serta air hujan yang jatuh kejalan sudah berubah warna menjadi warna tanah, jadi masyarakat Sungai Landia serta pemerintah sudah mewantiwanti dari awal jika hujan lebat yang berpotensi bencana tanah longsor.

\section{DAFTAR KEPUSTAKAAN}

Arifin, S., Carolila, I., Dan Winarso, C. (2006). Implementasi Pengindraan Jauh Dan Sig Untuk Inventarisasi Daerah Rawan Bencana Longsor. Jurnal Pengindraan Jauh Lapan, 3, 80-81.

Badan Penanggulangan Bencana Daerah Agam. (2017). Laporan Rekapitulasi Bencana Alam Di Kabupaten Agam. Agam.

Bayuaji, D., Nugraha, A., \& Sukmono, A. (2016). Analisis Penentuan Zonasi Risiko Bencana Tanah Longsor Berbasis Sistem Informasi Geografis (Studi Kasus: Kabupaten Banjarnegara). Jurnal Geodesi Undip, 5(1), 326-335. 
Muhammad Rizky Wahyudi, Zikri Alhadi I Pendekatan dalam Mitigasi Bencana Tanah Longsor di Kenagarian Sungai Landia Kecamatan IV Koto Kabupaten Agam

Karnawati, D. (2005). Bencana Alam Gerakan Massa Tanah Di Indonesia Dan Upaya Penanggulangannya. Teknik Geologi, Fakultas Teknik, Universitas Gadjah Mada, Yogyakarta. Jurusan Teknik Geologi, Fakultas Teknik, Universitas Gadjah Mada.

Lexi, J., \& M.A., M. (2010). Metodologi Penelitian Kualitatif. Metodologi Penelitian Kualitatif. Pt. Remaja Rosdakarya.

Nandi. (2007). Longsor. Bandung, 4, 4546.

Pemerintah Indonesia. (2008). Peraturan Presiden Republik Indonesia Tentang Badan Nasional Penanggulangan
Bencana. 1, 1-24.

Ramli, S. (2010). Pedoman Praktis Manajemen Resiko. In Dian Rakyat. Dian Rakyat.

Susanti, P. D., Miardini, A., \& Harjadi, B. (2017). Analisis Kerentanan Tanah Longsor Sebagai Dasar Mitigasi Di Kabupaten Banjarnegara. Jurnal Penelitian Pengelolaan Daerah Aliran Sungai, 1(1), 49-59.

Widiyanto. (2013). Kajian Persebaran Kerusakan Infrastruktur, Permukiman Dan Lahan Pertanian Akibat Banjir Lahar Hujan Tahun 2010 Dengan Pendekatan Geomorfologi. Jurnal Bumi Indonesia, 1(3). 